\title{
Subdivision in Franklin
}

\author{
ALEX TURNEY \\ Resource Management Consultant \\ Agriculture New Zealand, PO Box 8, Pukekohe
}

\begin{abstract}
Rural subdivision in South Auckland is influenced by four characteristics: 1) the change in lot sizes and the economic viability of land uses; 2) activity conflict between lifestylers and rural production activities; 3) the value of land for the proposed land use; 4) the costs and benefits associated with subdivision proposals. Rural subdivision has the potential to change the landscape, land uses, the rural environment and the community. Currently the area is made up of rural activities with an increasing number of rural residential activities encroaching into the rural area of south Auckland.
\end{abstract}

Keywords: amenity, economics, land use, land values, rural environment, rural subdivision

\section{Introduction}

Rural subdivision in the Franklin District and South Auckland has had a considerable impact on land use activities and natural resources. The history of land use in South Auckland has been dominated by the subdivision policies of both Papakura and Franklin District Councils. They have caused a marked change in the landscapes, land uses, the rural environment and the community.

For many rural land users the Franklin District (Counties) has a large number of advantages over other areas in New Zealand, including its soils, climate, proximity to markets and ports, labour availability and strong service industry as well as visual amenity. But how will rural South Auckland continue to benefit? Land values have increased by up to $180 \%$ over the last six years. The lot size to remain economically viable now stands at between 70 and 298 ha for a variety of pastoral land uses and the average lot size of rural land in Papakura and Franklin is approximately 4.3 and 13.5 ha respectively, with further subdivision approvals pending.

\section{What is subdivision?}

The term subdivision has not been specifically defined in the Resource Management Act, 1991 (RMA) however Section 218 of the Act deals with the "division of an allotment". Wharfe (1997) defined the term subdivision in a rural context as the division of any rural allotment whether it is a 1000 ha or 10 ha. Rural subdivision can be described in a number of forms:

- large blocks separating off a smaller portion to be treated as a separate farm unit;

- small blocks separated from a larger unit to become small holdings with an intended rural land use;

- small blocks separated from a larger unit to become lifestyle blocks; and

- rural-residential blocks separated from larger units which generally appear to be smaller and are concentrated in areas with blocks of similar size.

\section{Who is responsible for subdivision?}

District councils are responsible for land use and subdivision under RMA and each district has a substantially different case. For South Auckland the District Council's task of setting subdivision and land use policies is huge, as many factors must be taken into consideration in the future use of the district's land resource. Subdivision is driven by a number of factors (Agriculture NZ 1996), including trends in horticultural and agricultural markets, changes in subdivision regulations, desires for rural lifestyle living and pressures from urban sprawl and development, and land values. Subdivision is a contentious issue because in one way or another it affects all land users.

\section{Why does subdivision affect us?}

Subdivision has four distinctive characteristics. The first is concern about the reduction in lot sizes and the impacts on the economic viability of land uses. Some intensive horticultural land uses may require only $3-4$ ha to remain viable. However, pastoral systems need at least 70 ha for winter milk supply or up to 298 ha for sheep and beef finishing (MAF 1996a). The minimum economic lot size is increasing as the margins in primary production are squeezed. Many rural land owners are having to earn off-farm income to supplement farm revenue. Working off-farm is common among all farm types (MAF 1996b). Between $41 \%$ and $46 \%$ of dairy and sheep and beef farms sourced income off-farm. The report showed that, on average, almost half $(47.7 \%)$ of those with off-farm income considered it either important 
or essential for the household and just over a third (37.4\%) felt it was either important or essential to the farm business. It will be interesting to see what happens to this factor in pastoral systems in the future.

The horticultural boom in the early 1980s increased subdivision approval numbers considerably as people used the economic unit to justify the subdivision proposal. Franklin was one particular area that came under significant pressure, because of its advantages of topography, soils, climate and access to significant domestic markets. Most subdivision proposals used the horticultural provisions of the Franklin District Plan as a means for subdivision, rather than genuine intentions for horticultural use. In 1992 the Franklin District had some 8000 ha still farmed as larger-lot dairy or sheep and beef farms but subdivided on paper into 10 ha lots.

Papakura District (Papakura District 1996) is heavily fragmented with horticultural lots, those in the 1.0 to 8.0 ha lot size, which represent $49 \%$ of the total rural lots in the rural zone of Papakura. There is still some emphasis left on the land use activity, and the horticultural provisions are often used as a scapegoat to approve a subdivision application in both the Franklin and Papakura Districts.

Franklin District covers much of South Auckland from the southern rim of the Manukau harbour across to Hunua and Kaiaua then down to Glen Murray and Naike in the south, and then up the coast through Port Waikato and the Awhitu Peninsula. Most of this is rural land, its biggest urban area being Pukekohe Township. The lot size distribution in Franklin shows nearly 38\% of lots are between 1.0 and 8.0 ha in size, with $27 \%$ less than 0.5 ha and only $18 \%$ larger than 20 ha.

A joint Regional and District Council Study (ARC et al. 1990) in 1990 investigated the outcomes of lots created under various subdivisions. Of the 2442 new lots subdivided under general horticulture criteria, $78 \%$ are less than 8 ha and only $13 \%$ were actually used for horticulture. Linked with this is the increasing price of land and the price that city dwellers are prepared to pay to live in the rural environment. It demonstrates that there is in fact a large latent pool of lots that have great potential to be utilised for horticultural activities and the need for continued subdivision of the rural zone by councils is not required.

The second characteristic of subdivision is the conflict with small landholders-lifestylers over spraydrift, noise, odours and even visual impacts. The conflicts stem from the new residents in the rural environment imposing a set of ideals about the rural setting that are not correct. They don't imagine the smells of a silage stack or pig pen, the noise of a barking dog or tractor spreading fertiliser in the morning. This type of conflict can prevent a productive user of land from undertaking certain management activities that are needed to run a farm day to day. If the conflicts get worse what will happen to the agricultural community in south Auckland? The Proposed Franklin District Plan (Franklin District Council 1994) allows sounds that are typical in a given area even when they may not comply with the stated levels for noise. These sounds must be tolerated by all people. But how long will this continue as the rural environment becomes misinterpreted by small landholders and as they begin to influence the planning process? What is the farming community doing to promote itself in the planning process to counter the lifestyler's ideals?

The third characteristic of subdivision is that it provides an option to get out of the downward spiral from the previous two. Releasing capital by the sale of smaller tracts of land can substantially ease the burden of debt servicing at a time when money is extremely limited. The selling off of smaller tracts of land only fuels the fire of conflicts and instigates another issue land values. With the busy metropolis of Auckland at the doorstep, motorways and fast cars, rural south Auckland is becoming a nice viable option for those seeking the perceived peace and tranquility of the rural area, even at a high price. Land values have seen enormous increases in the last six years. Horticultural land in 1990 was valued at an average of NZ\$22,548 per ha and now at the end of 1996 the figure has risen to $\$ 64,964$ per ha. Pastoral land for dairy in 1990 was valued at $\$ 11,097$ per ha, now it's $\$ 22,161$ per ha (Valuation New Zealand 1990-96)

The fourth concern about subdivision is the costs and benefits that occurs with it. A study (Works Environmental Management \& Agriculture New Zealand 1995) highlighted seven environmental effects that would occur from five different scenarios of land use on a 160 ha block of land. The scenarios were pastoral dairy, lifestyle drystock, citrus, flowers, and small lot drystock. The environmental effects highlighted were: the demand on water and potential water quality problems; effluent discharge from the discharge of point source dairy effluent; waste water discharge from the significant increase in intensive land use; discharge of fertilisers; discharge of pesticides and herbicides; soil erosion; and activity conflict.

The benefits associated with the subdivision were noted in the study as the increased rates received by the councils, the income produced from the land use on the property and the multiplier effect of changing land use, i.e., more people spending money in the community and an opportunity to provide more goods and services.

The study also commented on the impact of subdivision on off-site and on-site amenity values. Further subdivision in Franklin will have a cumulative 
effect on valued natural landscapes. At times this will detract from the natural rural setting of much of the rural area. The further fragmentation and traffic generation in the rural environment impacts very heavily on rural amenity, and as Auckland grows and people continue to want to live in the rural environment, land uses will change dramatically as all the characteristics of subdivision get stronger and stronger.

\section{What is the future for Franklin District?}

Much of the future of the Counties area is in the hands of the planners in each of the District Councils. The trends of declining farm numbers, increasing land values, activity conflicts and reducing lot sizes in the Auckland region indicate that perhaps pastoral farming is giving way to a more intensive land use pattern throughout the region. The increasing pressure from those currently residing in the rural area may impose environmental expectations that curtail some of the current farming practices and force out the pastoral farmer. We are unlikely to see new entrances into the farming scene in the Auckland region because land values will exceed the value for an agricultural use, hence the land will become swallowed up into lifestyle land uses. What is the future of rural land in Franklin District?

\section{REFERENCES}

Agriculture New Zealand Ltd. 1996. Rural land use in the Auckland Region. Unpublished Report for Auckland Regional Council.

Auckland Regional Council, Franklin and Papakura District Council 1990. Study of outcomes of lots created under various subdivisions.

Franklin District Council 1994. Proposed District Plan. Ministry of Agriculture 1996. Farm monitoring report, North Region.

Ministry of Agriculture, Rural Resources MAF Policy 1996. Off-farm income survey. Technical Paper.

Papakura District Council 1996. Statistics of land parcels by group.

Valuation New Zealand 1990-96. Rural sales listing.

Wharfe, L. 1997. Subdivision of rural land: a review of the current situation. Unpublished report for MAF Policy.

Works Environmental Management \& Agriculture New Zealand Ltd. 1995. Cost benefit analysis of rural subdivision in Karaka, Franklin District. 
